\title{
ENDOSULFAN CONCENTRATIONS IN ASSOCIATION WITH SERUM BIOCHEMICAL PARAMETERS AND RISK OF CANCER
}

\author{
AtTAUllah, M. ${ }^{1 *}$ - YOUSUF, M. J. ${ }^{2}-$ AMIN, M. ${ }^{2}$ - BUNERI, I. D. ${ }^{2}$ - RAHIM, A. ${ }^{1}-$ ANJUM, S. I. ${ }^{3}$ - ILAHI, I. ${ }^{1}$ \\ ${ }^{I}$ Department of Zoology, University of Malakand, Chakdara-18800, Dir Lower, Pakistan \\ ${ }^{2}$ Department of Zoology, University of Karachi, Karachi-75270, Pakistan \\ ${ }^{3}$ Department of Zoology, Kohat University of Science and Technology, Pakistan \\ ${ }^{*}$ Corresponding author \\ e-mail: attaullah.ms@gmail.com; phone: +92-33-3244-3799
}

(Received $19^{\text {th }}$ Jan 2019; accepted $27^{\text {th }}$ Feb 2019)

\begin{abstract}
The present study was conducted to evaluate the association between residues of $\alpha$ endosulfan, $\beta$-endosulfan, endosulfan sulfate and total endosulfan ( $\Sigma$ endosulfan) with serum cholesterol, alkaline phosphatase (ALP) and total proteins (TP) in diagnosed cancer patients and healthy subjects of Karachi, Pakistan. Donors provided fasting blood samples with informed consent and serum was separated within two hours of blood collection through centrifugation at $2500 \mathrm{rpm}$. Levels of serum cholesterol, ALP and TP were quantified on Roche/Hitachi spectrophotometers while gas chromatograph (GC-17A) coupled with 63Ni electron capture detector was used for the quantification of endosulfan residues. Detected mean concentrations of $\alpha$-endosulfan, $\beta$-endosulfan and endosulfan sulfate were higher in the cases compared with controls $(p>0.05)$. Mean levels of serum cholesterol and TP were found significantly reduced in the cancer cases $(p<0.05)$ while ALP activity was found significantly elevated in the cancer cases compared with controls $(p<0.05)$. An association between endosulfan sulfate and cholesterol levels $(r=0.333)$ and between $\Sigma$ endosulfan and cholesterol $(r=0.245)$ was detected in the cancer cases but no such association was found in the control group. The presence of higher serum concentrations of $\alpha$-endosulfan, $\beta$-endosulfan, endosulfan sulfate and $\Sigma$ endosulfan associated with abnormal serum biochemical parameters may be a risk factor of various malignancies in humans.
\end{abstract}

Keywords: insecticide, cholesterol, ALP, total proteins, environmental pollutants

\section{Introduction}

Endosulfan is a broad spectrum organochlorine insecticide used around the globe in household and agriculture to control insect pests (Dilna et al., 2018). Endosulfan has been reported in human tissues, milk and serum samples (Latif et al., 2012; Khawaja et al., 2012; Khwaja et al., 2013; Saeed et al., 2017; Attaullah et al., 2018). Endosulfan consists of $\alpha$ and $\beta$ isomers in the ratio of 7:3 (Wan et al., 2005). The main endosulfan metabolite is endosulfan sulfate which is liphophilic and mainly accumulated in the adipose tissues (Cerrillo et al., 2005). Endosulfan causes a variety of disorders in humans including testicular cancer, prostate cancer and breast cancers (Soto et al., 1994; Romeo and Quijano, 2000; Saiyed, 2003; Ibarluzea et al., 2004), teratogenicity (Grumfeld and Bonefeld-Jorgensen, 2004; Singh et al., 2007; Silva and Beauvais, 2010), DNA damage (Bhalli et al., 2009) and neurotoxicity (ATSDR, 2015). Endosulfan damages human RBCs at concentrations ranging from $1 \mathrm{ppb}$ to $1 \mathrm{ppm}$ (Daniel et al., 1986).

Serum cholesterol is a useful biomarker of several metabolic disorders. Levels of serum cholesterol are mostly found diminished in the cancer patients compared 
with the healthy subjects (Ding and $\mathrm{Hu}, 2008$ ). There is a potential association between serum concentrations of chlorinated pesticides and serum cholesterol levels (Aminov et al., 2013; Singh and Chan, 2018). Alkaline Phosphatase (ALP) is found almost in all tissues and is comparatively stable in serum. ALP levels are found elevated in the cancer cases compared with controls as reported in colorectal carcinoma (Saif et al., 2005), breast cancer (Prabasheela et al., 2012) and osteosarcoma (Kim et al., 2017; Sahran et al., 2018).

Serum total protein contents is a good indicator for the assessment of various malignancies and stage of the disease as reported in squamous cell carcinoma (Nayyar et al., 2012). Several studies have shown a correlation between persistent organochlorine pesticide residues and alterations in enzyme levels (Azmi et al., 2006; Arshad et al., 2007; Dyk and Pletschke, 2011), serum proteins and ALP (Khan et al., 2008) and serum cholesterol, TP contents and ALP levels (Paccagnella et al., 1971).

Endosulfan is banned in Pakistan but is sold and used illegally on vegetables, fruits, crops and for other miscellaneous purposes as confirmed in recent studies across the country (Anwar et al., 2011; Randhawa et al., 2016; Ahmad et al., 2018; Hayat et al., 2018). It was therefore necessary to evaluate endosulfan residues with respect to health risk in humans. The present study was aimed to comparatively evaluate the concentrations of $\alpha$-endosulfan, $\beta$-endosulfan and endosulfan sulfate in the cancer cases and healthy subjects and to find out any potential association between endosulfan concentrations with serum cholesterol, ALP and TP contents.

\section{Materials and Methods}

Analysis of endosulfan isomers $(\alpha$ and $\beta$ ) and endosulfan sulfate, cholesterol, ALP and Total Proteins was carried out in sera of the diagnosed cancer cases $(n=$ $51)$ and healthy control subjects $(n=30)$ at Karachi, Pakistan. Mean ages and male to female ratio was (39.5 years, 47:53) in the cancer cases and (33.3 years, 90:10) in the controls respectively. The study was conducted in general population of Karachi, Pakistan with no past history of occupational exposure of the subjects to endosulfan. The study subjects were indirectly exposed to endosulfan due to intake of contaminated vegetables, food, water, fruit and milk. This shows exposure of the general population to endosulfan indirectly through food chain. Blood samples ( $8 \mathrm{ml}$ each) were collected randomly from the cancer patients and healthy subjects with informed consent at various hospitals of Karachi. Serum was separated from the blood within two hours of collection through centrifugation and was stored at $20{ }^{\circ} \mathrm{C}$ at the Toxicology Laboratory, Department of Zoology, University of Karachi. Extraction, purification and quantification of endosulfan in the serum samples was carried out according to the previously described methods (Dale et al., 1970; Atuma and Aune, 1999; Moreno Frias et al., 2001). The detailed protocol for the extraction of endosulfan residues, clean-up with florisil column and quantification through Gas Chromatography coupled with Electron Capture Detector (GC-ECD) has been described elsewhere (Attaullah et al., 2018).

Cholesterol analysis was carried out according to (Allain and Roeschlau, 1974) with Cholesterol Kit catalogue no. (CHOL 12016630 122), COBAS Registered was used for this purpose. About $3.0 \mu \mathrm{l}$ of the sample was mixed with $250 \mu 1$ of R1 
reagent. A photometric determination of the color intensity produced by hydrogen peroxide was made on Roche/Hitachi 902 analyzer.

ALP in the serum samples was processed according to (Bowers and McComb, 1975) with the help of ALP Kit catalogue no. (AP 7927) and quantification was carried out on HITACHI 717 Spectrophotometer, Randox Laboratories Ltd., UK. About $0.025 \mathrm{ml}(25 \mu \mathrm{l})$ of serum sample was mixed with $1.0 \mathrm{ml}$ of reagent and heated up to $37{ }^{\circ} \mathrm{C}$ for $5 \mathrm{~min}$. A yellow colored p-nitrophenol was produced at 405 $\mathrm{nm}$. The color intensity is a measure of the level of ALP in the sample.

Total Proteins in the serum were determined according to (Weichselbaum, 1946) with Kit catalogue no. (TP-11553836 316), COBAS Registered. Serum sample $(5 \mu \mathrm{l}$ each) was mixed with $90 \mu \mathrm{l}$ of $\mathrm{R} 1$ reagent, then $\mathrm{R} 2$ reagent $(90 \mu \mathrm{l})$ was added which formed a purple colored biuret complex. The color intensity of the biuret complex was quantified with Roche/Hitachi 902 Spectrophotometer at $546 \mathrm{~nm}$.

Statistical evaluation of the data was carried out using MS Excel Office Version 365 by calculating the mean values of endosulfan concentrations, cholesterol, ALP and Total Protein contents in the cancer cases and controls. The calculated mean values of the studied parameters were compared in the cases and controls through independent $t$ Test (two samples assuming unequal variances) with $p$ values less than 0.05 showing statistically significant difference between the cancer cases and controls. Values of Pearson correlation coefficient (r) between endosulfan and serum biochemical parameters were calculated in MS Excel and were confirmed statistically through regression analysis.

\section{Results}

Elevated mean concentrations of endosulfan isomers and endosulfan sulfate $(\mathrm{mg} / \mathrm{kg}$ wet weight serum) were detected in the cancer cases compared with controls. Mean levels of endosulfan in the cases versus control subjects were: $\alpha$ endosulfan $(0.043$ vs. $0.03, p=0.56), \beta$-endosulfan $(0.041 v s .0 .021, p=0.42)$, endosulfan sulfate $(0.104$ vs. $0.1, p=0.62)$ and $\Sigma$ endosulfan $(0.189$ vs. $0.153, p=$ 0.37) (Table 1).

Table 1. Mean levels $\pm S D$ of the studied parameters in the cancer cases and controls

\begin{tabular}{|c|c|c|c|c|c|c|c|}
\hline \multirow{2}{*}{ Studied Parameters } & \multicolumn{3}{|c|}{ Cases } & \multicolumn{3}{|c|}{ Controls } & \multirow{2}{*}{$\begin{array}{c}P \\
\text { values }\end{array}$} \\
\hline & Mean & SD & Range & Mean & SD & Range & \\
\hline$\alpha$-endosulfan (mg/kg) & 0.043 & 0.124 & $0-0.712$ & 0.03 & 0.06 & $0-0.231$ & 0.56 \\
\hline$\beta$-endosulfan (mg/kg) & 0.041 & 0.161 & $0-1.118$ & 0.021 & 0.044 & $0-0.183$ & 0.42 \\
\hline Endosulfan Sulfate $(\mathrm{mg} / \mathrm{kg})$ & 0.104 & 0.236 & $0-1.422$ & 0.1 & 0.183 & $0-0.771$ & 0.62 \\
\hline$\Sigma$ Endosulfan $(\mathrm{mg} / \mathrm{kg})$ & 0.189 & 0.364 & $0-2.134$ & 0.153 & 0.178 & $0-0.771$ & 0.37 \\
\hline Chol. (mg/dl) & 116 & 22.7 & $78-165$ & 157 & 34.9 & $82-225$ & $<0.05$ \\
\hline ALP (U/L) & 128 & 49.5 & $60-419$ & 109 & 28.6 & $71-223$ & 0.03 \\
\hline $\mathrm{TP}(\mathrm{g} / \mathrm{dl})$ & 6.2 & 0.57 & $4.5-7.3$ & 7.2 & 1.06 & $4.6-9.1$ & $<0.05$ \\
\hline
\end{tabular}

Legend: $\Sigma$ endosulfan $=$ Sum of the endosulfan isomers $(\alpha, \beta)$ and endosulfan sulfate, $\mathrm{SD}=\mathrm{Standard}$ Deviation. Normal ranges in an average adult human for cholesterol: < $200 \mathrm{mg} / \mathrm{dl}$; ALP: 30-120 U/L; Total Proteins: $6.0-8.0 \mathrm{~g} / \mathrm{dl}$ 
Cholesterol levels were found significantly diminished in the cancer cases compared with controls. The detected mean levels of cholesterol in the cancer cases versus controls were $(116 \pm 22.7 \mathrm{mg} / \mathrm{dl} v s .157 \pm 34.9 \mathrm{mg} / \mathrm{dl} ; p<0.05)$ (Table 1). ALP activity was found elevated in the cancer cases compared with controls. Mean ALP levels in cases versus controls were detected as $128 \pm 49.5 \mathrm{U} / \mathrm{L}$ vs. $109 \pm 28.6$ $\mathrm{U} / \mathrm{L} ; p<0.05)$ (Table 1$)$. Total Proteins in cases were found significantly reduced $(6.2 \mathrm{~g} / \mathrm{dl})$ compared with controls $(7.2 \mathrm{~g} / \mathrm{dl} ; p<0.05)$ (Table 1$)$.

In the cancer cases, Pearson correlation coefficient between endosulfan sulphate and cholesterol $(\mathrm{r}=0.333 ; p=0.02)$ and between $\Sigma$ endosulfan and cholesterol ( $\mathrm{r}$ $=0.245 ; p=0.08$ ) indicate a positive association between endosulfan and cholesterol levels as shown in Fig. 1. Correlation between endosulfan and ALP was found very weak in the studied cohort (Fig. 1). Statistical significance was not achieved between endosulfan residues and the studied parameters because significance level obtained was higher than 0.05 in all of the cases except between endosulfan sulphate and cholesterol $(\mathrm{r}=0.333 ; p=0.02)$ and between $\alpha$ endosulfan and TP $(\mathrm{r}=-0.303 ; p=0.03)$ in the cancer cases (Fig. 1).

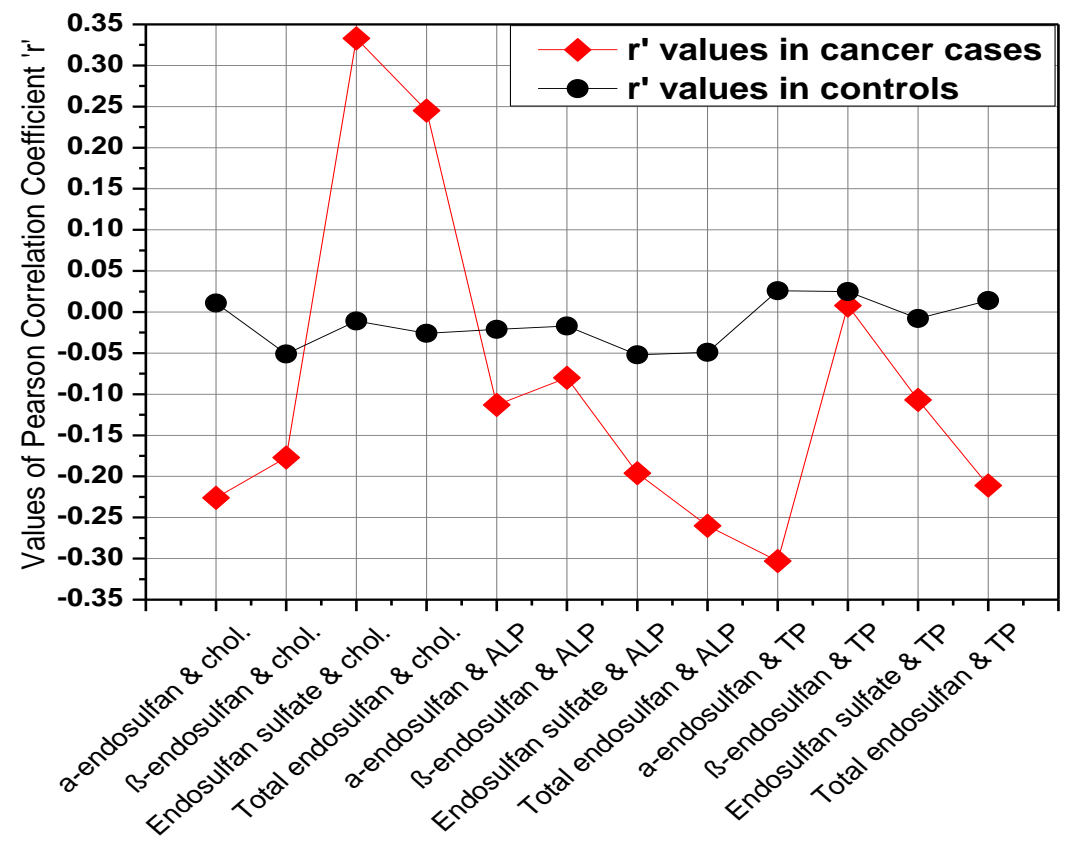

Figure 1. Correlation between endosulfan residues with serum Cholesterol (chol.), alkaline phosphatase (ALP) and total protein (TP) contents in the cancer cases and controls

In the major cancer sites, the Lymphatic system showed the lowest mean cholesterol level $(99.6 \mathrm{mg} / \mathrm{dl})$ with a higher concentration of endosulfan sulfate $(0.107 \pm 0.152$ $\mathrm{mg} / \mathrm{kg})$, reduced mean ALP level $(99 \pm 4.2 \mathrm{U} / \mathrm{L})$ and reduced mean TP level $(5.6 \pm 0.1$ $\mathrm{g} / \mathrm{dl}$ ) (Table 2). Highest ALP activity was detected in the blood cancer cases (148 \pm 30.7 $\mathrm{U} / \mathrm{L})$ with reduced mean cholesterol level $(102 \pm 19.1 \mathrm{mg} / \mathrm{dl})$ and a mean $\Sigma$ endosulfan level of $0.131 \pm 0.244 \mathrm{mg} / \mathrm{dl}$ (Table 2).

In the sub sites of cancer cases, lowest mean level of cholesterol was detected in Hodgkin's Lymphoma (HL) as $83 \mathrm{mg} / \mathrm{dl}$ with mean level of endosulfan sulfate as 0.215 $\mathrm{mg} / \mathrm{kg}$ and lowest mean level of TP $(5.5 \mathrm{~g} / \mathrm{dl})$ (Table 2). Highest mean cholesterol level 
was detected in the ovarian carcinoma $(151 \mathrm{mg} / \mathrm{dl})$ with significantly reduced level of $\alpha$ endosulfan $(0.007 \mathrm{mg} / \mathrm{kg})$ (Table 3).

Table 2. Mean levels \pm SD of the tested parameters in the studied major cancer sites

\begin{tabular}{|c|c|c|c|c|c|c|c|}
\hline $\begin{array}{c}\text { Major } \\
\text { Cancer } \\
\text { Sites }\end{array}$ & $\begin{array}{c}\begin{array}{c}\alpha- \\
\text { endosulfan } \\
(\mathbf{m g} / \mathbf{k g})\end{array} \\
\text { Mean } \pm \text { SD }\end{array}$ & $\begin{array}{c}\beta- \\
\begin{array}{c}\beta- \\
\text { endosulfan } \\
(\mathbf{m g} / \mathbf{k g})\end{array} \\
\text { Mean } \pm \text { SD }\end{array}$ & $\begin{array}{c}\text { Endosulfa } \\
\text { n Sulfate } \\
(\mathrm{mg} / \mathrm{kg}) \\
\operatorname{Mean} \pm \mathrm{SD}\end{array}$ & $\begin{array}{c}\Sigma \\
\begin{array}{c}\Sigma \\
\text { endosulfan } \\
(\mathbf{m g} / \mathbf{k g})\end{array} \\
\operatorname{Mean} \pm \mathrm{SD}\end{array}$ & $\begin{array}{c}\text { Chol. } \\
\text { (mg/dl) } \\
\begin{array}{c}\text { Mean } \pm \mathbf{S} \\
\text { D }\end{array} \\
\end{array}$ & $\begin{array}{c}\text { ALP } \\
(\mathbf{U} / \mathbf{L}) \\
\operatorname{Mean} \pm \mathbf{S} \\
\text { D } \\
\end{array}$ & $\begin{array}{c}\text { TP } \\
(\mathbf{g} / \mathbf{d l}) \\
\text { Mean } \pm S \\
\text { D } \\
\end{array}$ \\
\hline $\begin{array}{c}\text { Oral } \\
\text { Cavity, } \\
\text { Pharynx }\end{array}$ & $\begin{array}{c}0.007 \pm 0.01 \\
3\end{array}$ & $\begin{array}{c}0.089 \pm 0.08 \\
2\end{array}$ & $0.07 \pm 0.121$ & $0.167 \pm 0.054$ & $\begin{array}{c}104 \pm 23 \\
4\end{array}$ & $112 \pm 6.65$ & $6.5 \pm 0.5$ \\
\hline $\begin{array}{l}\text { Digestive } \\
\text { System }\end{array}$ & $\begin{array}{c}0.022 \pm 0.07 \\
1\end{array}$ & $\begin{array}{c}0.106 \pm 0.30 \\
9\end{array}$ & $0.075 \pm 0.11$ & $0.204 \pm 0.336$ & $\begin{array}{c}127 \pm 20 \\
7\end{array}$ & $133 \pm 87.3$ & $6.2 \pm 0.6$ \\
\hline $\begin{array}{l}\text { Respirator } \\
\text { y System }\end{array}$ & $\begin{array}{c}0.004 \pm 0.00 \\
8\end{array}$ & 0 & $0.085 \pm 0.17$ & $0.089 \pm 0.179$ & $\begin{array}{c}111 \pm 23 \\
3\end{array}$ & $\begin{array}{c}141.5 \pm 15 \\
9\end{array}$ & $5.9 \pm 0.1$ \\
\hline Breast & $\begin{array}{c}0.144 \pm 0.25 \\
2\end{array}$ & $\begin{array}{c}0.003 \pm 0.00 \\
6\end{array}$ & $\begin{array}{c}0.344 \pm 0.51 \\
5\end{array}$ & $0.492 \pm 0.708$ & $125 \pm 20$ & $108 \pm 21.8$ & $6.6 \pm 0.4$ \\
\hline Skin & $\begin{array}{c}0.007 \pm 0.01 \\
6\end{array}$ & $\begin{array}{c}0.006 \pm 0.01 \\
4\end{array}$ & $0.06 \pm 0.107$ & $0.074 \pm 0.101$ & $\begin{array}{c}107 \pm 14 \\
6\end{array}$ & $125 \pm 16.4$ & $6 \pm 0.3$ \\
\hline $\begin{array}{l}\text { Female } \\
\text { Genital } \\
\text { System }\end{array}$ & $\begin{array}{c}0.002 \pm 0.00 \\
3\end{array}$ & $\begin{array}{c}0.007 \pm 0.01 \\
4\end{array}$ & 0 & $0.009 \pm 0.012$ & $\begin{array}{c}136 \pm 24 \\
1\end{array}$ & $105 \pm 24.1$ & $6.1 \pm 0.8$ \\
\hline Blood & $\begin{array}{c}0.056 \pm 0.11 \\
7\end{array}$ & $\begin{array}{c}0.032 \pm 0.06 \\
7\end{array}$ & $\begin{array}{c}0.042 \pm 0.04 \\
9\end{array}$ & $0.131 \pm 0.224$ & $\begin{array}{c}102 \pm 19 \\
1\end{array}$ & $148 \pm 30.7$ & $6.1 \pm 0.5$ \\
\hline $\begin{array}{l}\text { Lymphati } \\
\text { c System }\end{array}$ & 0 & 0 & $\begin{array}{c}0.107 \pm 0.15 \\
2\end{array}$ & $0.107 \pm 0.152$ & $\begin{array}{c}99.5 \pm 23 \\
3\end{array}$ & $99 \pm 4.2$ & $5.6 \pm 0.1$ \\
\hline
\end{tabular}

Table 3. Mean levels $\pm S D$ of the tested parameters in the sub sites of cancer cases

\begin{tabular}{|c|c|c|c|c|c|c|c|}
\hline $\begin{array}{c}\text { Sub sites } \\
\text { of cancer } \\
\text { cases }\end{array}$ & $\begin{array}{c}\text { d- } \\
\text { endosulfa } \\
\text { n (mg/kg) } \\
\text { Mean } \pm \text { SD }\end{array}$ & $\begin{array}{c}\boldsymbol{\beta}- \\
\text { endosulfa } \\
\text { n (mg/kg) } \\
\text { Mean } \pm \text { SD }\end{array}$ & $\begin{array}{c}\text { Endosulfa } \\
\text { n Sulfate } \\
(\mathbf{m g} / \mathbf{k g}) \\
\operatorname{Mean} \pm \mathrm{SD}\end{array}$ & $\begin{array}{c}\Sigma \\
\text { endosulfa } \\
\mathbf{n}(\mathbf{m g} / \mathbf{k g}) \\
\operatorname{Mean} \pm \mathrm{SD}\end{array}$ & $\begin{array}{c}\text { Chol. } \\
(\mathrm{mg} / \mathrm{dl}) \\
\underset{\mathrm{Mean}}{\mathrm{D}} \pm \mathbf{S} \\
\text { D }\end{array}$ & $\begin{array}{c}\text { ALP } \\
(\mathbf{U} / \mathbf{L}) \\
\begin{array}{c}\text { Mean } \pm \mathbf{S} \\
\text { D }\end{array}\end{array}$ & $\begin{array}{c}\text { TP }(g / d l) \\
\underset{\text { Mean }}{ } \pm S \\
\text { D }\end{array}$ \\
\hline Tongue & $\begin{array}{c}0.011 \pm 0.01 \\
6\end{array}$ & $\begin{array}{c}0.081 \pm 0.11 \\
5\end{array}$ & $\begin{array}{c}0.105 \pm 0.14 \\
9\end{array}$ & $\begin{array}{c}0.198 \pm 0.01 \\
7\end{array}$ & $\begin{array}{c}111.5 \pm 27 \\
.5\end{array}$ & $110 \pm 6.3$ & $6.8 \pm 0.4$ \\
\hline Pharynx & 0 & $0.106 \pm 0$ & 0 & $0.106 \pm 0$ & $89 \pm 0$ & $118 \pm 0$ & $6 \pm 0$ \\
\hline $\begin{array}{c}\text { Esophagu } \\
\text { s }\end{array}$ & $\begin{array}{c}0.005 \pm 0.00 \\
8\end{array}$ & 0 & .053 & .05 & 17.3 & 24.2 & $6.4 \pm 0.8$ \\
\hline Stomach & 0 & $\begin{array}{c}0.559 \pm 0.78 \\
9\end{array}$ & $\begin{array}{c}0.042 \pm 0.05 \\
9\end{array}$ & $\begin{array}{c}0.601 \pm 0.84 \\
9\end{array}$ & $125 \pm 24$ & $119 \pm 5.65$ & $6.2 \pm 0.1$ \\
\hline Colon & $0.065 \pm 0.13$ & $\begin{array}{c}0.059 \pm 0.10 \\
1\end{array}$ & $\begin{array}{c}0.005 \pm 0.01 \\
1\end{array}$ & $\begin{array}{c}0.131 \pm 0.22 \\
8\end{array}$ & $131 \pm 18.4$ & $106 \pm 16.7$ & $6.3 \pm 0.3$ \\
\hline Rectum & 0 & $\begin{array}{c}0.007 \pm 0.01 \\
1\end{array}$ & $\begin{array}{c}0.146 \pm 0.13 \\
5\end{array}$ & $\begin{array}{c}0.153 \pm 0.14 \\
7\end{array}$ & $137 \pm 24.3$ & $205 \pm 186$ & $6 \pm 1.3$ \\
\hline Appendix & $0.01 \pm 0$ & 0 & $0.318 \pm 0$ & $0.328 \pm 0$ & $1+0$ & $113 \pm 0$ & $5.9 \pm 0$ \\
\hline Larynx & 0 & 0 & 0 & 0 & $102 \pm 0$ & $161 \pm 0$ & $6.2 \pm 0$ \\
\hline Lung & $\begin{array}{c}0.005 \pm 0.00 \\
9\end{array}$ & 0 & $\begin{array}{c}0.113 \pm 0.19 \\
6\end{array}$ & $\begin{array}{c}0.119 \pm 0.20 \\
6\end{array}$ & $114 \pm 27.6$ & $135 \pm 11.2$ & $5.9 \pm 0.1$ \\
\hline Breast & $\begin{array}{c}0.144 \pm 0.25 \\
2\end{array}$ & $\begin{array}{c}0.003 \pm 0.00 \\
6\end{array}$ & $\begin{array}{c}0.344 \pm 0.51 \\
5\end{array}$ & $\begin{array}{c}0.492 \pm 0.70 \\
8\end{array}$ & $125 \pm 20$ & $108 \pm 21.8$ & $6.6 \pm 0.4$ \\
\hline Neck & 0 & 0 & $0.13 \pm 0.171$ & $0.13 \pm 0.171$ & $97 \pm 2.8$ & $112 \pm 19.7$ & $5.8 \pm 0.5$ \\
\hline Cheek & $0.012 \pm 0.02$ & $0.011 \pm 0.01$ & $0.013 \pm 0.01$ & $0.037 \pm 0.02$ & $113 \pm 16.4$ & $134 \pm 8$ & $6.2 \pm 0.1$ \\
\hline
\end{tabular}




\begin{tabular}{c|c|c|c|c|c|c|c} 
& 1 & 9 & 1 & 8 & & & \\
Cervix & $0.002 \pm 0.00$ & $0.014 \pm 0.01$ & 0 & $0.016 \pm 0.01$ & $145 \pm 20.5$ & $108 \pm 41$ & $5.8 \pm 1.2$ \\
Ovary & 2 & 9 & & 6 & & & \\
Vagina & $0.007 \pm 0$ & 0 & 0 & $0.007 \pm 0$ & $151 \pm 0$ & $104 \pm 0$ & $6.1 \pm 0$ \\
ALL & $0.007 \pm 0.01$ & $0.004 \pm 0.00$ & $0.024 \pm 0.03$ & $0.036 \pm 0.02$ & $113 \pm 5.13$ & $136 \pm 8.5$ & $6.2 \pm 0.6$ \\
& 2 & 6 & 6 & 9 & $05 \pm 0$ & $98 \pm 0$ & $6.8 \pm 0$ \\
AML & $0.092 \pm 0.14$ & $0.053 \pm 0.08$ & $0.049 \pm 0.05$ & $0.195 \pm 0.28$ & $92.8 \pm 11$. & $143 \pm 34.9$ & $6.2 \pm 0.6$ \\
& 6 & 3 & 5 & 1 & 5 & & \\
CML & 0 & 0 & $0.048 \pm 0.06$ & $0.048 \pm 0.06$ & $120 \pm 39.5$ & $182 \pm 1.4$ & $5.7 \pm 0.2$ \\
HL & 0 & 0 & $0.215 \pm 0$ & $0.215 \pm 0$ & $83 \pm 0$ & $102 \pm 0$ & $5.5 \pm 0$ \\
NHL & 0 & 0 & 0 & 0 & $116 \pm 0$ & $96 \pm 0$ & $5.7 \pm 0$ \\
\hline
\end{tabular}

Legend: $\mathrm{ALL}=$ Acute Lymphoblastic Leukemia; $\mathrm{AML}=$ Acute Myeloid Leukemia; $\mathrm{CML}=$ Chronic Myeloid Leukemia; HL= Hodgkin's Lymphoma; NHL= Non-Hodgkin's Lymphoma.

\section{Discussion}

Endosulfan is a widely used insecticide worldwide and has been associated with various malignancies in human and animal studies. The present study was conducted to evaluate the potential association of endosulfan residues with serum biochemical parameters and to ascertain the possible role of endosulfan residues in causing various malignancies in humans. Findings of the present study are consistent with the previous cases-control studies on the association of endosulfan with various cancers in humans (Kumar et al., 2010; Arrebola et al., 2015; Shah et al., 2018). Serum mean cholesterol levels and Total Proteins were found significantly reduced in the cancer cases compared with controls $(P<0.05)$ while serum ALP levels were found elevated in the cancer cases than controls $(P<0.05)$ (Table 1$)$. Similar findings in cancer cases versus controls have been detected in previous studies for cholesterol levels (Mufti and Baseer, 1996; Memon et al., 2007; Chawda et al., 2011; Ahmad et al., 2012), for Total Protein levels (Nayyar et al., 2012) and for ALP levels (Saif et al., 2005; Prabasheela et al., 2012).

Variations in levels of serum cholesterol, ALP and TP from the normal levels indicate the severity of disease in various cancers and can be utilized as diagnostic and prognostic biomarkers.

An association between endosulfan sulfate and cholesterol $(\mathrm{r}=0.333)$ and between $\Sigma$ endosulfan and cholesterol $(\mathrm{r}=0.245)$ has been detected in the cancer cases. A very weak association between $\alpha$-endosulfan and cholesterol $(r=0.011)$ has been detected in the control subjects (Fig. 1). This indicates that endosulfan concentrations are associated with cholesterol levels and support the previous literature on the subject (Aminov et al., 2013; Singh and Chan, 2018; Fadaeipuor et al., 2016). Endosulfan and organochlorine pesticides residues increases with increasing levels of serum cholesterol and declines with decreasing levels of cholesterol. In the present study, although levels of cholesterol were significantly lower in the cancer cases but the residues of endosulfan were higher in the cancer cases in comparison with controls (Table 1). Apparently, reduction in cholesterol level may be an immune mechanism for decreasing the lipid pool in serum and thus reducing the storage reservoirs for lipophilic toxic chemicals in the body. Another reason for the reduced cholesterol levels in the cancer cases may be due to the adverse effects of higher endosulfan 
residues in the cancer cases. A weaker association was found between endosulfan and ALP in the cases compared with controls (Fig. 1).

Serum endosulfan concentrations detected in the present study may not be capable to affect ALP activity as indicated by the weak association from the Pearson correlation coefficient (Fig. 1). Highest ALP activity (148 U/L) was found in the blood cancer cases while lowest was found in cases of the lymphatic system (99 U/L) (Table 2). In the blood cancer cases, detected mean levels of endosulfan were: $\alpha$ endosulfan $(0.056 \mathrm{mg} / \mathrm{kg}), \beta$-endosulfan $(0.032 \mathrm{mg} / \mathrm{kg})$, endosulfan sulfate $(0.042$ $\mathrm{mg} / \mathrm{kg}), \Sigma$ endosulfan $(0.131 \mathrm{mg} / \mathrm{kg})$ with reduced mean level of cholesterol (102 $\mathrm{mg} / \mathrm{dl}$ ) and elevated level of ALP (148 U/L) (Table 2). This indicates that the altered levels of cholesterol and ALP might be due to the presence of high endosulfan concentrations. Lowest cholesterol level (99.5 mg/dl), lowest ALP level (99 U/L) and lowest TP level $(5.6 \mathrm{~g} / \mathrm{dl})$ were detected in cases of the lymphatic system with detected mean conecentration of endosulfan sulfate as $0.107 \mathrm{mg} / \mathrm{kg}$ (Table 2). The altered parameters in lymphatic system is indicative of the role of endosulfan sulfate in cases of the lymphatic system. A similar pattern was also detected in cases of AML, Neck and Appendicular Carcinoma (Table 3).

In cases of Hodgkin's Lymphoma, reduced mean TP level $(5.5 \mathrm{~g} / \mathrm{dl})$, lowest mean cholesterol level amongst sub sites $(83 \mathrm{mg} / \mathrm{dl})$ and significantly elevated mean level of endosulfan sulfate $(0.215 \mathrm{mg} / \mathrm{kg})$ were detected (Table 3$)$. This indicates a possible role of endosulfan sulfate in the risk of HL and an association with cholesterol and TP levels.

In the sub sites of cancer cases, highest ALP activity was found in cases of the rectal carcinoma and CML while lowest was detected in cases of NHL (Table 3).

The overall results indicate that cancer cases are having higher residues of endosulfan compared with controls. Serum cholesterol and total proteins are significantly lower in the cancer cases compared with controls while ALP activity was higher in the cancer cases compared with controls. There was a positive association between endosulfan residues and serum cholesterol levels in the cancer cases, but no such association was detected in the controls. Presence of lower cholesterol levels and higher endosulfan residues simultaneously may act as risk factors of various malignancies in humans. The overall results indicate that the cancer cases are having higher serum concentrations of endosulfan associated with abnormal levels of serum biochemical parameters compared with the control group.

\section{Conclusion}

The presence of higher serum concentrations of $\alpha$-endosulfan, $\beta$-endosulfan, endosulfan sulfate and $\Sigma$ endosulfan associated with abnormal serum biochemical parameters may be a risk factor of various malignancies in humans. Further work is recommended to ascertain the actual causes of endosulfan toxicity focusing on the mechanisms underlying alterations of serum biochemical parameters and associated health risks in humans and experimental animals. 


\section{REFERENCES}

[1] Ahmad, A., Shahid, M., Khalid, S., Zaffar, H., Naqvi, T., Pervez, A., Bilal, M., Ali, M. A., Abbas, G., Nasim W. (2018): Residues of endosulfan in cotton growing area of Vehari, Pakistan: an assessment of knowledge and awareness of pesticide use and health risks. - Environmental Science and Pollution Research. https://doi.org/10.1007/s11356018-3169-6

[2] Ahmad, S. S., Ashraf, S., Jamal, A. (2012): Total serum cholesterol level in cases of carcinoma breast-A correlative study. - Journal of Advanced Laboratory Research in Biology 3(2): 58-61.

[3] Allain, P., Roeschlau, A. (1974): Cholesterol determination. - Journal of Clinical Chemistry: 195-207.

[4] Aminov, Z., Haase, R. F., Pavuk, M., Carpenter, D. O., Anniston. (2013): Analysis of the effects of exposure to polychlorinated biphenyls and chlorinated pesticides on serum lipid levels in residents of Anniston, Alabama. - Environmental Health 12(1): 108.

[5] Anwar, T., Ahmad, I., Tahir, S. (2011): Determination of pesticide residues in fruits of Nawabshah District, Sindh, Pakistan. - Pakistan Journal of Botany 43(2): 1133-1139.

[6] Arrebola, J. P., Belhassen, H., Artacho-Cordón, F. et al. (2015): Risk of female breast cancer and serum concentrations of organochlorine pesticides and polychlorinated biphenyls: A case-control study in Tunisia. - Science of the Total Environment 520: 106113.

[7] Arshad, N., Shabbir, G., Aleem, S., Arshad, M. (2007): Effects of $\alpha$-Tocopherol on liver biochemistry of Endosulfan intoxicated mice: A preliminary study. - Asian Journal of Experimental Sciences 21(2): 239-246.

[8] ATSDR (2015): Toxicological profile for Endosulfan. - Agency of Toxic Substances and Disease Registry, U.S. Department of health and human services.

[9] Attaullah, M., Yousuf, M. J., Shaukat, S., Anjum, S. I., Ansari, M. J., Buneri, I. D., Tahir, M., Amin, M., Ahmad, N., Khan, S. U. (2018): Serum organochlorine pesticides residues and risk of cancer: a case-control study. - Saudi Journal of Biological Sciences 25: 12841290.

[10] Atuma, S. S., Aune, M. (1999): Method for the determination of PCB congeners and chlorinated pesticides in human serum. - Bulletin of Environmental Contamination and Toxicology 62: 8-15.

[11] Azmi, M. A., Naqvi, S. N. H., Azmi, M. A., Aslam, M. (2006): Effect of pesticide residues on health and different enzyme levels in the blood of farm workers from Gadap (rural area) Karachi- Pakistan. - Chemosphere 64: 1739-1744.

[12] Bhalli, J. A., Ali, T., Asi, M. R., Khalid, Z. M., Ceppi, M., Khan, Q. M. (2009): DNA damage in Pakistani agricultural workers exposed to mixture of pesticides. Environmental and Molecular Mutagenesis 50: 37-45.

[13] Bowers, G. N., McComb, R. B. (1975): Measurement of total alkaline phosphatase activity in human serum. - Clinical Chemistry 21(13): 1988-1995.

[14] Cerrillo, I., Granada, A., Lopez-Espinosa, M. J., Olmos, B., Jimenez, M., Cano, A., Olea, N., Olea-Serrano, M. F. (2005): Endosulfan and its metabolites in fertile women, placenta, cord blood, and human milk. - Environmental Research 98: 233-239.

[15] Chawda, J. G., Jain, S. S., Patel, H. R., Chaduvula, N., Patel, K. (2011): The relationship between serum lipid levels and the risk of oral cancer. - Indian Journal of Medical Paediatrics and Oncology 32(1): 34-7.

[16] Dale, W. E., Miles, J. W., Gaines, T. B. (1970): Quantitative method for determination of DDT and DDT metabolites in blood serum. - Journal - Association of Official Analytical Chemists 53: 1287-1292.

[17] Daniel, C. S., Agarwal, S., Agarwal, S. S. (1986): Human red blood cell membrane damage by endosulfan. - Toxicology Letters 32(2): 113-8. 
[18] Dilna, C., Prasanth, G. K., Kanade, S. R. (2018): Molecular interaction studies of endosulfan with the cholinergic pathway targets - An insilico approach. - Computational Toxicology 5: 1-7.

[19] Ding, E. L., Hu, F. B. (2008): Cancer and cholesterol: understanding the V-shaped association in patients with diabetes. - Journal of Canadian Medical Association 179(5): 404.

[20] Dyk, J. S. V, Pletschke, B. (2011): Review on the use of enzymes for the detection of organochlorine, organophosphate and carbamate pesticides in the environment. Chemosphere 82: 291-307.

[21] Fadaeipuor, S., Babaei, Z., Parsian, H., Motevalizadeh, A. A., Nikbakhsh, N. (2016): Comparison of the serum total bile acids and cholesterol levels in breast cancer patients with control group. - Journal of Babol University of Medical Sciences 18(8): 48-53.

[22] Grumfeld, H., Bonefeld-Jorgensen, E. C. (2004): Effects of invitro estrogenic pesticides on human oestrogen receptor alpha and beta mRNA levels. - Toxicology Letters 151: 467-480.

[23] Hayat, K., Afzal, M., Aqueel, M. A., Khan, Q. M. (2018): Determination of insecticide residues in fruits, vegetables, pollen, nectar and ground water of Punjab (Pakistan). Journal of Agriculture Research 56(2): 95-105.

[24] Ibarluzea, J. J., Fernandez, M. F., Santa, M. L., Olea, S. M. F., Rivas, A. M., Aurrekoetxea, J. J. et al. (2004): Breast cancer risk and the combined effect of environmental estrogens. - Cancer Causes and Control 15(6): 591-600.

[25] Khan, D. A., Bhatti, M. M., Khan, F. A., Naqvi, S. T., Karam, A. (2008): Adverse effects of pesticides residues on biochemical markers in Pakistani tobacco farmers. International Journal of Clinical and Experimental Medicine 1: 274-282.

[26] Khawaja, S., Yousuf, M. J., Azmi, M. A., Attaullah, M., (2012): Monitoring of pesticide residues hexachlorocyclohexane, cyclodiene, diphenylaliphates and their metabolite in the breast milk of women from Karachi, Pakistan. - Medical Forum 23(5): 19-22.

[27] Khwaja, S., Rubina, M., Rehana, M., Yousuf, M., Attaullah, M., Tabassum, F., Faiz, R. (2013): Monitoring of biochemical effects of organochlorine pesticides on human health. - Health 5(8): 1342-1350.

[28] Kim, S. H., Shin, K., Moon, S., Jang, J., Kim, H. S., Suh, J., Yang, W. (2017): Reassessment of alkaline phosphatase as serum tumor marker with high specificity in osteosarcoma. - Cancer Medicine 6(6): 1311-1322.

[29] Kumar, V., Yadav, C. S., Singh, S., Goel, S., Ahmed, R. S., Gupta, S., Grover, R. K., Banerjee, B. D. (2010): CYP 1A1 polymorphism and organochlorine pesticides levels in the etiology of prostate cancer. - Chemosphere 81: 464-468.

[30] Latif, Y., Sherazi, S. T. H., Bhanger, M. I., Nizamani, S. (2012): Evaluation of pesticide residues in human blood samples of agro-professionals and non agro-professionals. American Journal of Analytical Chemistry 3: 587-595.

[31] Memon, N. Q., Memon, J. Q., Khan, A. W. (2007): Serum cholesterol levels and incidence of ovarian tumours in Pakistani women. - Pakistan Journal of Physiology 3(1): 23-25.

[32] Moreno Frias, M., Garrido Frenich, A., Martinez Vidal, J. L., Mateu Sanchez, M., Olea, F., Olea, N. (2001): Analyses of lindane, vinclozolin, aldrin, p,p'-DDE, o,p'-DDT and $\mathrm{p}, \mathrm{p}$ '-DDT in human serum using gas chromatography with electron capture detection and tandem mass spectrometry. - Journal of Chromatography B: Biomedical Sciences and Applications 760: 1-15.

[33] Mufti, T. A., Baseer, A. (1996): Cholesterol and lipids in cancer patients. - Journal of the Pakistan Medical Association 10(1): 19-24.

[34] Nayyar, A. S., Khan, M., Vijayalakshmi, K., Suman, B., Gayitri, H., Anitha, M. (2012): Serum total protein, albumin and advanced oxidation protein products (AOPP) implications in oral squamous cell carcinoma. - Malaysian Journal of Pathology 34(1): $47-52$. 
[35] Paccagnella, B., Ghezzo, F., Prati, L., Fedrazzoni, U., Belloni, G. (1971): Epidemiological study of long-term effects of pesticides on human health. - Bulletin of World Health Organization 45: 181-199.

[36] Prabasheela, B., Baskaran, S., Arivazhagan, R. (2012): Evaluation of alkaline phosphatase in pre and post-operative breast cancer patients. - International Journal of Biological and Medical Research 3(2): 1536-1537.

[37] Randhawa, M. A., Abid, Q. U. Z., Anjum, F. M., Chaudhary, A. S., Sajid, M. W., Khalil, A. A. (2016): Organochlorine pesticide residues in okra and brinjal collected from periurban areas of big cities of Punjab - Pakistan. - Pakistan Journal of Agricultural Sciences 53(2): 425-430.

[38] Romeo, F., Quijano, M. D. (2000): Risk assessment in a third world reality: An endosulfan case history. - International Journal of Occupational and Environmental Health 6(3-4): 383-394.

[39] Saeed, M. F., Shaheen, M., Ahmad, I., Zakir, A., Nadeem, M., Chishti, A. A., Shahid, M., Bakhsh, K., Damalas, C. A. (2017): Pesticide exposure in the local community of Vehari District in Pakistan: An assessment of knowledge and residues in human blood. - Science of the Total Environment 587-588: 137-144.

[40] Sahran, Y., Sofian, A. M., Saad, A. Z. M., Zulmi, W., NorAzman, M. Z., Faisham, W. I. (2018): Pre-treatment serum lactate dehydrogenase (LDH) and serum alkaline phosphatase as prognostic factors in patients with osteosarcoma. - Journal of Cancer Prevention and Current Research 9(2): 58-63.

[41] Saif, M. W., Alexander, D., Wicox, C. M. (2005): Serum alkaline phosphatase level as a prognostic tool in colorectal cancer: A study of 105 patients. - Journal of Applied Research 5(1): 88-95.

[42] Saiyed, H., Dewan, A., Bhatnagar, V., Shenoy, U., Shenoy, R., Rajmohan, H. et al. (2003): Effect of endosulfan on male reproductive development. - Environmental Health Perspectives 111: 1958-1962.

[43] Shah, H. K., Bhat, M. A., Sharma, T., Banerjee, B. D., Guleria, K. (2018): Delineating potential transcriptomic association with organochlorine pesticides in the etiology of epithelial ovarian cancer. - Open Biochemistry Journal 12: 16-28.

[44] Silva, M. H., Beauvais, S. L. (2010): Human health risk assessment of endosulfan I: toxicology and hazard identification. - Regulatory Toxicology and Pharmacology 56: 417.

[45] Singh, K., Chan, H. M. (2018): Association of blood polychlorinated biphenyls and cholesterol levels among Canadian Inuit. - Environmental Research 160: 298-305.

[46] Singh, N., Sharma, A., Dwivedi, P., Patil, R., Kumar, M. (2007): Citrinin and endosulfan induced teratogenic effects in Wistar rats. - Journal of Applied Toxicology 27(2): 143151.

[47] Soto, A. M., Chung, K. L., Sonnenschein, C. (1994): The pesticides endosulfan, toxaphene, and dieldrin have estrogenic effects on human estrogen-sensitive cells. Environmental Health Perspectives 102: 380-383.

[48] Wan, M. T., Kuo, J. N., Buday, C., Schroeder, G., Aggelen, G. V., Pasternak, J. (2005): Toxicity of $\alpha-, \beta,(\alpha+\beta)$-Endosulfan and their formulated and degradation products to Daphnia magna, Hyalella azteca, Oncorhynchus mykiss, Oncorhynchus kisutch, and biological implications in streams. - Environmental Toxicology and Chemistry 24(5): $1146-1154$.

[49] Weichselbaum, T. E. (1946): An accurate and rapid method for the determination of proteins in small amounts of blood serum and plasma. - American Journal of Clinical Pathology 16: 40-49. 